\title{
Uma leitura de $O$ príncipe com orelhas de burro de José Régio
}

Nadiá Paulo Ferreira Universidade Estadual do Rio de Janeiro

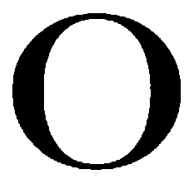

livro Oprincipe com orelbas de burro aponta para alguns compromissos estéticos com o movimento presencista. Em 1927, a revista Presença, criada por José Régio, João Gaspar Simões e Branquinho da Fonseca, funda um movimento artístico que, segundo os historiadores da literatura portuguesa, inaugura a segunda fase do modernismo português. Este movimento visava retomar a contribuição do grupo Orpbeu (Lisboa, 1915), que inseriu a literatura portuguesa no compasso da modernidade, e dar continuidade ao projeto órphico de revisio da literatura portuguesa para resgatar os seus grandes momentos.

O modernismo português, ao contrário do Futurismo (1909) e do modernismo brasileiro (São Paulo, Semana de Arte Moderna, 1922), não apresenta uma postura radical contra o passado. Os integrantes de Orpheu (1915), ao contrário dos futuristas, não se voltaram com fúria contra a tradiçào da literatura portuguesa. Eles têm como proposta a revalorizaçào das obras que contribuíram com originalidade para a construçào de uma literatura nacional. Fernando Pessoa, por exemplo, considera Antônio Vieira o maior prosador e artista da língua portuguesa e a Pátria, de Guerra Junqueiro, a obra mais importante daqueles últimos trinta anos, vindo, inclusive, na frente de Os lissiadas, que ocuparia "honrosamente o segundo lugar".' Aliás, para Fernando Pessoa, os dois grandes escritores que antecederam o modernismo foram Guerra Junqueiro e Antônio Nobre: "o

' PESSOA, 1976. p. 343. 
de Pátria e Finis Patriae - foi a face que olla para o Futuro, e se exalta. Antônio Nobre foi a face que olha para o Passado, e se entristece".

Além dos compromissos estéticos de Presença, o recurso da alegoria, no sentido de Walter Benjamin, aponta para uma relação entre texto e contexto, totalmente diferente da concebida pelo neorealismo, cujas fontes são os textos de Marx e de Engels.

Traslândia é um lugar fictício. Isto não significa, em momento algum, que este romance não esteja insericlo na história e na cultura portuguesas. Simplesmente, o modo pelo qual se inscreve não segue o modelo historicista do neo-realismo. Uma voz paralela, tecendo comentários à margem, acompanha o relato do narrador. Na justaposição destes dois narradores, como se fosse ponto e contraponto, os eventos, ao mesmo tempo, têm como cenário o reino de Traslândia e como referência episódios da história de Portugal.

Se o reino de Traslândia estava ameaçado pelo perigo de não ter um sucessor, quantas vezes essas ameaças não se abateram sobre Portugal? Em 1580, a ausência de um sucessor fez com que Portugal perdesse sua soberania e passasse sessenta anos sob o domínio espanhol. Do drama português às vicissitudes do homem, uma história é contada para falar de Portugal e representar as relações do homem com o poder, que vão desde a subserviência até a revolta dos oprimidos, que encontram na violência o caminho para lutar em Nome-da-Liberdade. A taberna da Zizi Gorda é o local de encontro dos marginalizados pela fome, dos miseráveis que perderam a dignidade humana:

Mesteirais, vagabundos, mendigos, desempregados, homens de profissão incerta ou suspeita, (...) Meia dúzia de fêmeas havia entre tantos homens. Grosseiramente pintadas, os ombros e os braços nus, o cabelo em juba tinham estampada no rosto uma bestialidade ou decadência que nem em todos os seus companheiros atingira tal grau.'

\footnotetext{
2 PESSOA, 1976, p. 344.

' RÉGIO, 1978. p. 163.
} 
A taberna da Zizi Gorda é o grande palco alegórico em que se encena a revolta inconsistente de uma parcela do reino que encontra refúgio e alento na bebida. Os freqüentadores da taberna se colocam à espera do Salvador, o Grande Chefe, o Pai, que irá conduzi-los às portas do palácio para depor o rei. Estas vãs ilusōes, sustentadas pelo estado de embriaguez, conduzem à revolução ou à espera com fé. Depende da oratória do Grande Chefe, com a qual todos histericamente se identificam. Assim, da euforia de combate, insuflada por um dos chefes, ao discurso de persuasão do príncipe Leonel, a festa acaba, quando Zizi bota toda "a cambada na rua". Mas, mesmo assim e nem assim, os neo-realistas souberem escutar José Régio. Por ironia do destino ou por excesso de paixão, os neorealistas acusaram os escritores presencistas de alienados e de nefelibatas. José Régio, talvez por sua posição de líder do movimento, em função da visão estreita que os neo-realistas tinham da função social da arte, foi o mais atacado. Acusaram-no de ter ignomdo às questões socialis de Portugal e do seu tempo.

Na construção alegórica do herói, José Régio reproduz, paralelamente, os acontecimentos e as versões que cercaram o nascimento do rei $\mathrm{D}$. Sebastião e que contribuíram para a formação do messianismo em torno deste rei, depois do seu trágico desaparecimento em Alcácer-Quibir, na manhã de 4 de agosto de 1578.

\section{O perigo se abate sobre o reino em função da sucessão}

Os avós de D. Sebastiào, D. João III e a Rainhà D. Catarina, assistiram à morte de nove filhos. Só dois sobreviveram: D. Maria e D. João. A filha, D. Maria, se casou com o príncipe Felipe, futuro rei de Portugal com a morte de $D$. Sebastião, morrendo logo depois do nascimento do seu fillo, príncipe D. Carlos. O fillo, D. João, desde o nascimento era muito fraco e doente. Seus pais resolveram,

+ RÉGIO, 1978. p.163. 
então, providenciar o seu casamento o mais rápido possível. Com quatorze anos de idade, D. João se casa com a prima, D. Joana, morrendo de uma crise de diabetes, antes do nascimento de seu filho: D. Sebastião. Segundo a maioria dos historiadores, D. João amava intensamente sua jovem esposa e eles foram separados assim que souberam que D. Joana estava grávida. E mais: esconderam a morte do marido até que seu filho nascesse.

No romance, trata-se de um casal que se amava profundamente, mas a "ausência de filhos nesse matrimônio representava uma desgraça pública".5 A rainha Elsa morre, logo depois do parto, com uma "réstia de sorriso sobrenatural na boca entreaberta"," depois de ter mostrado ao rei as pequeninas orelhas de burro do seu filho recém-nascido. Esta marca hedionda não só é um presságio, mas também simboliza a fragilidade que se abate sobre os corpos dos herdeiros portugueses, inclusive, do próprio D. Sebastiāo. Segundo António Machado Pires, D. Sebastiāo, aos onze anos de idade, conforme as cartas dos embaixadores espanhóis em Portugal, guardadas no Arquivo Geral de Simancas, já sofria de uma enfermidade que preocupava a corte.

A enfermidade em questào apresentava como sintomas principais uma purgação anormal por via genital e um estado febril persistente. O repouso e a abstençìo de diversðes violentas melhoravam ligeiramente D. Sebastiăo; mas foi uma esperança ilusória de cura, pois a enfermidade agravou-se, perante a perplexidade dos médicos, que nào chegavam a um acordo no diagnostico. $O$ doente sofria agora de outros sintomas ainda: tonturas, mal-estar e desmaios. A aflição que se procluziu na corte, no ânimo da rainhn-avó e do Cardeal D. Henrique, em breve se transmitiu à mãe de D. Sebastião, há muito afastada de Portugal. Esta mandou o seu médico pessoal a Lisboa, para proceder a exame cuidadoso, a cuja terapêutica posterior, ao que parece, a doença nio cedeu. Todas as vezes que $D$. Sebastiāo regressava aos seus desportos favoritos - caçar e cavalgar horas e horas - piorava sensivelmente.?

'REGIO, 1978. p. 7.

6 REGIO, 1978. p. 27.

' PIRES, 1982. p. 45-46. 


\section{Regozijo nacional, expectativas de glória e profecias em torno do nascimento do futuro rei}

O povo de Traslândia, tal qual o povo português, segundo os discursos histórico e literário da época, esperava ansiosamente o nascimento do futuro herdeiro do trono.

Evoé! Voara por todo o reino a grande nova! E começara uma festa pegada (...) uma onda de alegria irresistível subia, irrompia cle tuclo e por tudo se espraiava, só porque uma nova pequenina vida ia clıegar ao mundo... Deus a trouxesse a salvamento! Deus a resguardasse e protegesse! E que fosse um menino! Que fosse um maz! Que fosse um homem! O reino precisava dum senhor para o futuro."

(...) E veio a salvamento. E era um rapaz. A noite de dores da rainha correu toda em preces públicas. Os templos ardiam de velas e regurgitavam de fieis. Diante do palácio, um mar de povo aguardava.'

Em torno de D. Sebastião, o Desejado, cria-se uma expectativa nacional e os escritores não param de lhe vaticinar um destino sem par. Leonel, quando nasce, também terá o seu destino traçado, só que quem irá profetizá-lo sĩo as três bruxas e o Gênio da Floresta. Dizem as bruxas:

- A praga que the rogo - (...) é que tenha todas as qualidacles que fazem um homem respeitado dos homens: Será inteligente, valente, leal...,

- A praga que lhe rogo - (...) é que tenha todas as qualidades que tornam um homem desejado das mulheres: Será belo, forte, másculo...

- A praga que lhe rogo - (...) é que tenha todas as qualidades que tornam um principe querido do seu povo: Será justo, generoso, enérgico... ${ }^{10}$

\footnotetext{
RÉGIO, 1978. p. 17.

9 REGIO, 1978. p. 19.

${ }^{10}$ RÉGIO, 1978. p. 20.
} 
E acrescenta o Gênio da Floresta:

- Parvas! (...) Pois a prenda que the eu dei é que tenha um defeito hediondo, capaz de corrigir todas as vossas prendas: Serí um príncipe perfeito com orelhas de burro!"

Difícil não apreender a ironia de José Régio em torno da mistificação e da esperança que se criou em torno de D. Sebastiào. A rainha sacrifica a sua vida, acreditando que assim o reino estará salvo, D. Sebastião morre lutando contra o povo bárbaro e infiel para cumprir a missão divina, que é a de espalhar a fé cristã pelo mundo. $\mathrm{E}$ alguns portugueses encontram no delírio a solução mágica para um amor que se sustenta do retorno de um rei-morto. Diz a rainha ao morrer:

- Bem sabia (...) que o nosso filho seria marcado pelo destino. Só um sacrifício dele e um meu permitiriam o seu nascimento. Aceitei o dele, porque me foi prometido que o seu destino seria grande... e sei que será grande... apesar de tudo! O meu, embora penoso agora que poderia ser eu tảo feliz, aceito-o gostosamente. ${ }^{12}$

Camōes dedica Os lusiadas a D. Sebastiāo:

E vós, ó bem nascida segurança

Da lusitana antiga liberdade, E não menos certíssimal esperança

De aumento da pequena Cristandade;

Vós, que esperamos jugo e vitupério

Do torpe Ismaelita cavaleiro,

Do Turco oriental e do Gentio

Que inda bebe o licor do santo Rio, (...)

Diogo Bernardes, o moço de toalha de D. Sebastião, que foi a Alcícer Quibir, exalta o rei no Lima:

"REGIO, 1978. p. 21.

"REGIO, 1978. p. 26.

is CAMÖES, 1979. p. 61. Canto I, 6-8. 
Cristo c'o vosso braço fará guerra

A todo o imigo seu, e o torpe mouro

Largando vos irá o vale e a serra

A ticloria uos chama, que esperais:

Pero de Andrade Caminha escreveu:

Dele se esperam milagrosos feitos, que milagres lbe está o céu promelendo. ${ }^{\text {is }}$

E do rei, D. Sebastiāo, temos o testemunho escrito:

Terey a Deos por fim de todas as minhas cousas, e em todas ellas me lembrarey delle;

Trabalharey por dilatar a fé de Cristo, para que se convertào todos os infieis;

Fazer mercês a bous, e castigar a maos."

\section{Certeza paranóica e morte inesperada}

Tanto D. Sebastião quanto Leonel estão a serviço de uma missão, têm uma fé inabalável e acreditam que detêm a verdade. Tanto um quanto outro morrem envolvidos em circunstâncias misteriosas, 0 que faz com que de alguma forma seja abolida a morte, na medida em que alguma coisa irá sobreviver à própria morte.

Do rei pouco se soube. A história fixou que ele combateu denotadamente e se embrenhou pela hoste inimiga até mais não ser visto. ${ }^{17}$ Agora é que ele queria a vida, agora que vencera a sua disformidacle, e era agora que ia morrer, senti-o. ${ }^{18}$

\footnotetext{
14 Fragmento de um poema de Digo Bernardo. In: PIRES 1982. p. 43.

15 Fragmento de um poema de Pero Andrade Caminla. In: PIRES, 1982. p. 43.

16 Fragmento de "Pensamentos" de D. Sebastião. In: PIRES, 1982. p. 45.

17 PIRES, 1982. p. 56.

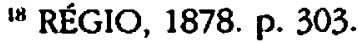


A princesa Letícia era uma mulher forte. E bem precisava de sê-lo, para defender o perigoso tesoiro que lhe legara o marido! Desse tesoiro fazia parte uma formazinha que já se mexia em seu ventre, - o filho do principe perfeito com orelhas de burro. A dinastia estava salva."

Rolāo Rebolão, "um poeta maluco e aleijado", ${ }^{20}$ cujo nome tem uma sonoridade que nos faz rir, representa, alegoricamente, a atopia do artista. Rolão como rolo rola por todos os lugares sem pertencer a nenhum, está sempre deslizando, é escorregadio. Mas também sabe enrolar. Mesmo sendo sincero no que diz e no que faz, é visto como um enrolão, já que ninguém entende a sua poesia e acha que é "fala de doido". Rolão significa também uma espécie de ave, cuja carne é muito apreciada, porque tem fama de ser muito saborosa. Rolão se delicia com sua própria poesia e nesta gustação de si mesmo encontra um gozo na sua criação. Rebolão (de rábula?) é sinônimo de individuo fanfarrão, impostor, bravateador. É quem gosta de fanfarrice, fanfarronada e fanfarria. Rolão Rebolão sabe que, para se manter na corte, é preciso rebolar. Ele se desloca como uma bola, entra em qualquer lugar, mesmo sem ser chamado, está sempre bisbilhotando:

(...) a cada instante se via Rolão Rebolão despenhar-se nas escadas, rebolar pelos corredores, encolher-se debaixo dos moveis, pinchar de trás dos reposteiros, sumir-se nos recantos. ${ }^{21}$

É também reboleiro, porque nào é fisgado facilmente e faz barulho e tumulto como um chocalho. Quando menos se esperava, lá estava - "poeta estrambótico, casquinando a sua risada histérica e Sarcástica"!'22 Rolão Rebolão é o poeta consumido como bobo da corte pela nobreza e pelo povo de Traslândia. Mas também é o único

"REGIO, 1878. p. 306.

20 REGIO, 1878. p. 31.

21 RÉGIO, 1978. p. 78.

22 RÉGIO, 1978. p. 79. 
que pode dizer o que pensa e tem livre acesso a todos os cantos e salōes do palácio. Pode falar, porque não é levado a sério, não é escutado. O bobo - demeuré, fool - é, segundo Lacan, "um parvo, mas por sua boca saem verdades, que não apenas são toleradas, mas que encontram sua funçìo, pelo fato de que esse fool é por vezes revestido das insignias do bufâo." ${ }^{23}$ Alegoriza-se com esta personagem o impasse do artista, não só em Portugal, mas em qualquer parte do mundo, segundo a visão de José Régio. Para ele, o artista freqüenta e é sustentado pelo poder, desde que seja consumido como um palhaço. $O$ artista ou diverte os poderosos ou se situa à margem das relaçōes de poder. Entretanto, para José Régio, isto não tem importância, porque está se falando do homem e não de sua obra. Se a obra é rotulada de incompreensivel e ninguém lhe dá ouvidos, então as formas de exercício do poder não só estão consolidadas como também conseguiram silenciá-la. Esse ostracismo da obra de arte permanece quando ela é sacralizada, tornando-se um troféu, o que significa que ela não será lida, embora vá fazer parte de algum museu. Mas o artista é aquele que não pára de produzir. Por quê? Porque é instigado pelo desejo e pelo gozo do qual usufrui com seu ato de escrita. Na construção alegórica de Rolão Rebolão, que aglutina todas essas contradições, temos a concepção da obra de arte para José Régio, que, tal qual o gozo, não tem função utilitária. Para Régio, um artista vale por sua obra e nela não pode haver concessão:

Isto $\mathrm{c}$ muito mais dizia por esse tempo Rolào Rebolào, num poemal que entào passara despercebido. A não passar despercebido, ainda mais incompreendido fora! Todavia, é hoje considerado uma obra prima. ${ }^{24}$

Num poema doido como os de Rebolão, cujos poemas eram dojdos, sinceros, livres, porque não falavam senão do que ele sabia, - pode um poeta arriscar-se a quantas revelações, confissỏes, confidências

25 LACAN, 1988. p. 223 ,

${ }^{24}$ REGIO, 1978. p. 59. 
e audácias lhe apraza! Ninguém as entende. Quando desconfia entendê-las, fica na dúvida. Quando nào duvida, é que é um irmào: nilo denunciará. ${ }^{25}$

Grifei duas palavras no trecho acima, para marcar o ideal de autenticidade que sustenta o projeto estético de José Régio, sem dúvida, o grande teorizador do presencismo. No texto Literatıra Viua, publicado no primeiro número da revista Presença, em 10 de março de 1927, vamos encontrar as seguintes afirmações: "Em Arte, é vivo tudo o que é original. Da pouca originalidade da literatura portuguesa, naturalmente resulta em grande parte a sua pouca sinceridade".

O homem se torna cego e surdo a qualquer coisa que não se enquadre aos padrões idealizados do eu. Os neo-realistas foram sinceros e autênticos em suas críticas aos presencistas, na medida em que estabeleceram um paradigma para a relação entre texto e contexto. Eles partiram do pressuposto de que a literatura tinha uma função social, que era a de contribuir para as transformações do quadro político, social e econômico de Portugal. E, por acreditarem nisso, o valor que serviu de parâmetro para julgamento estético foi o da função social da arte: denunciar as mazelas da sociedade portuguesa. Desta forma, o único caminho a ser percorrido seria construir uma ficção que remetesse de forma explícita para um contexto claramente identificado na história social. Diz Alves Reclol, na abertura de Gaibéus:

Este romance não pretende ficar na literatura como obra de arte.

Quer ser, antes de tudo, um documentário humano fixado no Ribatejo.

Depois disso, será o quie os outros entenderem. ${ }^{77}$

25 RÉGIO, 1978. p. 67.

* REGIO, 1977. p. 17.

27 REDOL, 1979. p. 53. 
É óbvio também que esta apologia da sinceridade do artista é uma forma de negar a existência do inconsciente como produçào de um saber não-sabido. Se o autor, tal qual todos nós, seres falantes, está submetido às leis da linguagem (estrutura do significante), que são as mesmas que as do inconsciente, por que ele escaparia de dizer além do que pensa que foi dito? Como colocar em pauta a questão da sinceridade, como sinônimo de autenticidade, senào eliminando a existência do inconsciente? O sujeito, nos adverte Lacan, "no nivel do inconsciente mente. E esta mentira é sua maneira de dizer a verdade acerca disso". ${ }^{28}$

É importante estabelecer uma diferença entre José Régio, teorizando sobre a arte e o artista, e sua obra. Esta, independente do que ele diz que acredita, está aí para ser lida e interpretada. Isto não significa que não possamos encontrar resquícios do sujeito José Régio em sua obra. Toda vez em que a narração é suspensa, dando lugar a comentários sobre o narrado, vamos encontrar na fala do narrador os ideais estéticos e egóicos do autor. A ironia reside justamente na coincidência entre os comentários do narrador de $O$ principe com orelbas de burro e as posiçōes dos neo-realistas em relação à obra de arte. O ponto comum entre eles é a idealizaçào da verdade. O que os diferencia é a solução encontrada para consubstanciar este ideal.

$O$ homem, a partir do momento em que é inscrito no simbólico (ordem do significante), pode vir a se tornar um criador, isto é, um artesão do significante. A criação não é outra coisa senão um trabalho com o significante, uma tessitura de relaçōes em torno do impossivel, forma pela qual o real, enquanto origem de tudo, se inscreve no simbólico. Isto é sublimação para Lacan. Neste sentido, a literatura como escrita é sublimação. Toda criação nasce de alguma coisa para "representar a existência do vazio no centro do real que se chama Coisa." ${ }^{29}$ Esta Coisa (Das Ding freudiano) é a invenção de

LACAN, 1988. p. 94.

9 LACAN, 1988. p. 53. 
um objeto. Para que serve a obra de arte? Para o gozo de quem a faz e para o gozo de quem a usufrui. E o gozo? Para que serve? Absolutamente para nada. Nem para manter um corpo vivo, já que não se pode viver só de gozo. A anorexia está aí para ilustrar um gozo que literalmente se sustenta de nada, levando o corpo à morte. Do mal-estar de não servir para nada se origina a noção do bem e do mal. Por conseguinte é preciso recalcar o mal-estar, atribuindo à obra de arte uma função social. Lacan, ${ }^{30}$ no Seminário $7, A$ ética da psicanálise, afirma que a procura pela fonte do mal coloca o homem diante de três escolhas: a obra, a matéria e o amor com a função de sublimação. A obra de arte, como paradigma da sublimação, é uma modelagem do significante que inclui um vazio, apontando para a existência de uma hiância entre o simbólico e o real.

José Régio apropria-se da lógica mítica das novelas de cavalaria, operando transformações que desmistificam a glorificação do herói. A primeira frase do romance é o sintagma "era uma vez", típico dos relatos míticos e das estórias infantis ("Era uma vez, no reino de Traslândia, um casal que não tinha filhos"31). A referência às aventuras cavaleirescas do ciclo bretão e à literatura infantil

30 “O mal está na matéria. Mas o mal pode também estar alhures. A questāo permanece aberta, e é certamente um pivô indispensável para compreender o que aconteceu historicamente no que se refere ao pensamento moral em tomo do problema do mal. O mal pode estar não apenas nas obras, não apenas nessa execrável matéria - daí todo o esforço da ascese vai consistir em dela se afastar, sem cair num mundo que chamam de místico, e que pode, igualmente, parecer-nos mítico ou mesmo ilusório -, o mal pode estar na Coisa.

Pode estar na Coisa dado que ela não é o significado que guia a obra, dado que tampouco é a matéria da obra, mas, dado que, no âmago do mito da criação ao qual está suspensa toda a queståo (...) ela define o humano, embora justamente, o humano nos escape.

Neste ponto, o que chamamos de humano não poderia ser definido de outra maneira senão por aquela com a qual defini, há pouco, a Coisa, ou seja, o que do real padece do significante ( LACAN, 1988. p. 155-156-157). 31 REGIO, 1978. p. 7. 
inscrevem-se no projeto estético de Presença, que tem como meta incorporar, no presente, "tudo o que é vivo do passado para que se torne clássico no futuro". ${ }^{32}$

Os procedimentos invariantes das narrativas míticas são:

1 - o herói pertence a uma família ilustre;

2 - o nascimento do herói é precedido por dificuldades que têm que ser ultrapassadas:

3 - o destino do herói é anunciado por figuras mágicas;

4- ao fim da narrativa, depois de muitas peripécias, confirmase a profecia e o herói alcança grandeza e glória.

Além da incorporação destes procedimentos para serem modificados, José Régio se apropria de outros recursos técnicos das novelas de cavalaria. A nomeação dos capítulos, anunciando o que será narrado, coloca em cena dois narradores: um que tem a função de participar a leitor o que será contado e outro que faz parte da narração propriamente dita. A presença destes dois narradores implica a justaposição de duas lógicas temporais: o futuro anterior, que caracteriza, através da repetição, o eterno retorno do tempo mítico e o presente da narração propriamente dita. Ao final cle cada capítulo, o círculo se fecha c o segundo narrador relata exatamente o que já tinha sido anunciado pelo primeiro. A prolixidade dos títulos está diretamente ligada a este procedimento.

Os tempos mítico e narrativo, por sua vez, irão se articular com a divisão dos personagens e dos espaços. Os personagens humanos são aqueles que vivem os eventos e passam pelas provas, mas desconhecem as suas significações. Os personagens sobrenaturais são aqueles que não passam por nenhuma prova, mas detêm o saber. Quanto ao espaço, temos o palácio, suas redondezals e o mistério da espessa floresta. Sempre que o limite entre estes dois espaços é ultrapassado o efeito é catastrófico. A rainha, ao ir para

32 Ver o texto publicado no número 1 da Retrista Presença, intitulado "Literatura Viva". 
a floresta, espaço da magia, paga com a própria vida a dádiva (gravidez) que recebeu. E o filho, produto do intercâmbio entre o humano e o não-humano, irá trazer no corpo a marca desse pacto sinistro.

Há ainda um terceiro narrador cuja função é tecer comentários à margem do que está sendo contado.

Aqui, uma breve divagação: Com o andar dos tempos, de bom ou mau grado acabara toda a gente por aceitar a autoridade do Aio. Lutar em vão contra o que dura - cansa. Nada assegura o poder, quer de um individuo quer de um governo, como simplesmente manter-se no poder.33

(...) Aquela burguesia que se preocupa com a nobreza, e para se aproximar dela lhe arremeda os costumes, as manias, os tiques, os vícios, (até as possíveis virtudes!) não deixara de, nesse particular, a copiar. E aquela camada do pou que se julga desgraçada por nào possuir a honorabilidade e os hábitos da burguesia, - até nessa moda já copiada, ou recopiada, quisera ter a aparência de burguesia; c imitara os burgueses. ${ }^{\text {t4 }}$

A constante intromissão, no relato do segundo narrador, freqüentemente cai no proselitismo. Às vezes, temos a impressão de que o autor quer destrinchar os efeitos polissêmicos da alegoria. Não temos condiçōes de saber. Talvez, este recurso tenha sido o meio que encontrou para reagir às acusações que lhe eram feitas pelos neo-realistas, que estavam tão obcecados por uma literatura de denúncia, que ficaram surdos e cegos inclusive ao didatismo de José Régio. Não nos esqueçamos de que a primeira publicação deste romance data de 1942 e que a primeira cisão no grupo presencista se deu na década de trinta, quando foi redigida a Carta, que depois ficou conhecida como a Carta dos dissidentes, assinada por Branquinho da Fonseca, Edmundo Bettencourt e Adolfo Rocha. E exatamente, a partir desta época, com a publicação de $A$ selva de Ferreira de Castro (1930), que se inicia a movimentação em torno

"s REGIO, 1978. p. 72. (O grifo é meu.)

it RÉGIO, 1978. p. 75. (O grifo é meu.) 
da função social da literatura, que irá desembocar, em 1939, com a publicação de Gaibéuıs de Alves Redol, no neo-realismo.

Retomando a apropriação dos procedimentos da narrativa do ciclo bretão, os personagens, que pertencem ao espaço mágico $\mathrm{c}$ não participam diretamente dos acontecimentos, são, como já dissemos, aqueles que detêm um saber. Trata-se de um saber com valor universalizante de verdade, que é ratificado a cada prova deceptiva ou glorificante do herói, fazendo com que estes personagens possam ser tomados como representantes do Outro, enquanto sujeito-suposto-saber. Justamente por isto, a função destes personagens se caracteriza pela sustentação da dicotomia entre os tempos mítico e narrativo. A cada ação realizada pelo herói (tempo narrativo) se confirma o que foi predito (tempo mítico). O futuroanterior do tempo mítico se ratifica no tempo narrativo, produzinclose, assim, um entrecruzamento entre estes dois tempos. A cada prova glorificante ou deceptiva se confirma a profecia, o que farz com seja atribuido à verdade um valor absoluto. Logo após o nascimento do príncipe, o aparecimento do Gênio da Floresta, que rarissimas vezes adquire forma visivel ao ollar dos humanos, remete para outra cena não descrita pela narração - $a$ ida da rainha à Floresta Encantada -, confirmanclo a existência de um pacto.

(...) Entretanto, o velho atravessara a multidão, passou entre os guardas, subiu escadarias, deslizou ao longo de corredores e saloes. Nào o veriam os guardas, os lacaios, os cortesàos, as camareiras? Grande era ele, e bem de se ter, com seus braços e pernas imitunles a troncos, suas barbas que torrencialmente lhe inundavam o peito e o ventre, sua basta cabeleira revolvida como densa moita em que se encafurnam os ventos, sulas feiçöes cortadas em angulosidades de rocha vilia..."

(...) Todos os olhos das nobres donas se voltaram igualmente para a porta. E nenhuma delas viu nada; nem ninguém. A seus olhos se furtava a extraordiniria presença que se revelara o monstro sem pernas. O parecer daquelas pobres nobres donas - era que ningućm

"REGIO, 1978. p. 21-22. 
abrira a pesada porta da câmara... Todavia, todas estavam arrepiadas: É que o doairo da rainha era sobrenatural! (...) Era claro que a rainha viu alguém que ninguém mais via. Conversava com quem mais ninguém ouvia..$^{36}$

(...) Só com o marido, a pobre màe rentou reclinar-se na cama, puxou o filho a si, tirou-lhe a touca de rendas.

- Reparai... (...) Nada lhe faltava; nada tinha a mais. Só aquelas orelhas de bicbo..."3

Algumas semelhanças entre esta cena, a entrada de Galaaz, o predestinado, no palácio do rei Artur em $A$ demanda do santo Graal e o episódio do gigante Adamastor em Os lusíadas merecem ser assinaladas. $O$ aparecimento de Galaaz é marcado por fenômenos extraordinários.

Eles em esto falando catarom e virom que todalas portas do paaço çarrarom e todalas freestas pero que nom escureceu por ende o paaço, ça entrou $\mathrm{i}-\mathrm{u}-\mathrm{u}$ tal raio de sol, que per toda a casa se estendeu. E aveo entam - ua gram maravilha: nom houve tal no paaço que nom perdessa a fala. ${ }^{3.8}$

O maravilhoso, além do sentido religioso de milagre, tem a função de avisar a todos os presentes que chegou a hora de acontecer o que já tinha sido previsto, ao nivel profético: os cavaleiros da Távola Redonda devem sair em busca do Graal. O gigante Adamastor é uma figura tão horrenda quanto o Gênio da Floresta. Ambos têm grandíssima estatura e aparecem para castigar o triunfo alcançado. Adamastor profetiza infortúnios para os portugueses, que, com a ajuda de Vênus, apesar das armadilhas de Baco, ousaram navegar nos seus "longos mares e ver os segredos escondidos da natureza e do úmido elemento, feitos a nenhum grande humano concedidos". ${ }^{39}$

\footnotetext{
* REGIO, 1978. p. 23-24.

${ }^{37}$ REGIO, 1978. p. 24-25. (O grifo é meu.)

* A DEMANDA DO SANTO GRAAL, 1995. p. 29.

y) CAMÖES, 1979. p. 138-239. C. V, 39 a 42.
} 
A rainha recebeu o apoio das três bruxas e teve o Gênio da Floresta como antagonista, porque ousou penetrar em seus domínios. Ela morreu acreditando que, apesar do infortúnio, o príncipe e o reino estariam salvos e teriam um futuro glorioso. Se José Régio não deixal de homenagear Camōes, o mais importante é o que está por trás desta referência alegórica apontando para o mito que se constituiu em torno do rei D. Sebastião. Nem Portugal nem Traslândia foram salvos. O rei e o príncipe morreram no empenho da grandeza de seus reinos. A esperança permanece na ressurreiçào do rei e no filho do príncipe que irá nascer...

Encontrar o Graal, descobrir uma nova rota marítima para as Índias e nascer um herdeiro são apresentados como questões cruciais pelas narrativas, em seus respectivos gêneros. A intervenção do mágico remete para a confluência do cristianismo mesclado às lendas bretãs na Idade Média e ao politeísmo greco-latino da Antigüidade.

A omissão da cena em que a rainha penetra nos domínios do Gênio da Floresta contribui para o clima de mistério em torno do nascimento do herdeiro. O narrador deixa entrever a existência de um pacto entre a rainha e o Gênio da Floresta, o que implica a suposição de que ela já sabia de três coisas: o pai de seu filho não era o rei; morreria assim que seu filho nascesse; o principe teria todas as qualidades de uma criança maravilhosa, com exceção de alguma coisa que seria a marca corporal da herança paterna.

O ponto é que já se esparaiva o luar quando a rainha voltou; (...) A rainha vinha cheia de pó, cambados e rotos os seus sapatinhos verdes, amarrotada toda a seda da saia. Até trazia rubis de sangue na cara. No seu sorriso como nos seus olhos, porém, raiava um clario que poucos viram, (...) Viu-o, de verdade, El-Rei, que nào era cego cle todo.

(...) $\Lambda$ rainha arrastou seu marido para a câmara régia. Aninhando-se-lhe aos pés, disse-lhe:

- Pensei muito durante este passeio... Nào mo censureis, porque decidiu da nossa vida. Estou resolvida a afastar-me para que outra vos clê o filho que vos nào posso dar... (...) 
- Nunca tive tanta fé, meu senhor. Por amor de vós, ousei consultar o génio da Floresta; ir até onde me nào julgara capaz... (...)

- Meu querido!... - suspirava ainda a rainha pela noite adiante. E, sentindo-se desejado, solicitado com vibrante sinceridade, ele afogava em beijos ardentes como os das suas primeiras noites de amor essa meiga apelaçào que já se ia desacostumando de ouvir...*

Alguns meses passaram. Se os homens nào fossem cegos, veriam que nos olhos da rainha, como no seu sorriso, um clarao continuava a anunciar grandes coisas. Nem seu marido, porém, tornou a reparar nesse indício, que uma tarde lhe gerara nos lábios palavras de exprobaçào e cólera."

A ironia e a ambigüidade nāo deixam de estar presentes, quando as três bruxas, que eram "três boas fadas" 42 disfarçadas, profetizam o que do ponto de vista do código deveria ser tomado como prenda, mas é nomeado de praga. Segundo a crendice popular, o que se repete três vezes têm valor de verdacle, justamente por isto, quando falamos ou escutamos alguma coisa que não queremos que aconteça, batemos três vezes na madeira. O Gênio da Floresta, insultando as três bruxas de parvas, diz que irá doar uma prenda para seu príncipe a fim de reparar os "mimos" 43 das bruxas, deixando o leitor surpreso, porque a referida prenda é "um defeito hediondo": "4 "um príncipe perfeito com orelhas de burro". 45

As três bruxas, tal qual Urganda (Amadis de Gaula) e Merlim (Demanda do sanlo Graal), no lugar de sujeito-suposto-saber, vaticinam o destino do herói. O príncipe, tal qual Amadis, será a criança maravillosa envolvida pelo enigma? Mas, ao contrário deste

\footnotetext{
4" RÉGIO, 1978. p. 11-12.

+ RÉGIO, 1978. p. 12-13.

42 REGIO, 1978. p. 20.

13 RÉGIO, 1978. p. 21.

"RÉGIO, 1978. p. 21.

"s RÉGIO, 1978. p. 21.
} 
herói cavalheiresco, não encontrarã uma mulher como Oriana para salvá-lo do seu destino.

O Gênio da Floresta retorna para gravar no corpo do filho a marca de sua paternidade. As orelhas de burro, enquanto metáfora do pai real, devem ser recalcadas pelo significante, vindo do campo do Outro, para que nosso herói seja inscrito no regime da Lei, humanizando-se. Com a introdução do simbólico, o real recalcado só pode recomparecer sob a forma de falta, inaugurando o desejo. Mas o rei, ao ver as orelhas de burro no recém-nascido, toma a seguinte decisão: a monstruosidade deve ser escondicla de todos, inclusive do próprio príncipe. Assim cresce nosso personagem sem sofrer a ação do recalque primário, vendo-se como um ser a quem nada falta...

Um príncipe precisa de um preceptor. Todos estupefatos assistem ao rei escolher um estranho sem nome, que surge no palácio, e passa a ser chamado de Aio, desaparecendo depois da mesma forma que apareceu: "Foi junto do seu leito de morte que pela última vez se viu o misterioso Aio". ${ }^{66}$

Quem é este preceptor? O Gênio da Floresta, aquele que pode assumir qualquer forma? O Aio, enquanto pai real, vem cumprir o pacto que tinha siclo feito com a rainha. As orelhas de burro, como metáfora do que está fora do significante, encarnam-se no real do corpo, em conformidade com o desejo da màe. Sem marcação do Nome-do-Pai, sem habitar o regime da Lei, portanto sem desejo $\mathrm{e}$ sem limite, nosso personagem flutua na folia, onde todos os objetos são incorporados ou rejeitados, segundo a lei do Princípio do Prazer. Real e imaginário sem a mediação do simbólico estruturam a relaçĩo do príncipe consigo mesmo e com a realidade que o cerca.

Leonel, imerso na ilusão de plenitude, se vê como falo. É deste lugar que toma para si a missĩo de reformar o mundo e restaurar a ordem, corriginclo todas as injustiçals. O reino, sob seu governo, nada mais será que a continuação de si mesmo. A fé inabalável nesta missão impossivel é o que sustenta seu delírio paranóico.

* RÉGIO, 1978. p. 305. 
O Aio, enquanto pai real, isto é, representante do Outro não castrado (Outro Absoluto, Outro sem barra), toma o lugar do rei, enquanto pai simbólico, a partir do desejo da mãe (pacto com o Gênio da Floresta). $O$ rei, aquele que é incapaz de engravidar a rainha, ameaçando a sucessão e fazendo com que o reino claudique, não pode exercer nem a função simbólica do pai, nem a função imaginária do pai real como agente privador do bem. O rei, como pai imaginário, não tem nenhuma atribuição fálica. Esta imagem de impotência nos é reapresentada, quando o príncipe, ao tomar conhecimento de suas orelhas de burro, sai, pela primeira vez, dos muros do palácio, e vai andar pelas ruas:

- O Urso!... Lá vem o Urso!... repetiram várias vozes à roda de Leonel. O tom dessas vozes excluía o respeito; acusava, mesmo, escárnio; (...)

"Com efeito!" pensou o principe Leonel "parece um urso! Temse feito um urso!" (...)

De facto, o bom rei Rodrigo acabara-se muito nos últimos anos.Nem aincla tinha idade para tal decadência. ${ }^{47}$

Inesperadamente, um riso meio abafado rastilhou nas primeiras alas do povo, comunicou-se às que mal saibam do que se tratava. É que ao descer, e apesar de se apoiar em Leonardo e no preceptor, ElRei tropeçara nas próprias vestes largas e longas; tivera um modo aflito, quase grotesco, e um galão de que se despenha. ${ }^{48}$

Leonel disse consigo, espantado: "Mas sim, parece um urso! Está velho! decrépito! Como tenho eu podido não ver a sua velhice? Só hoje..." O seu espanto misturava-se de inquietação, e.. como poderí dizer-se?... duma espécie de alegria. Parecia a Leonel que novos sentidos se the estavam desabrochando. "Velho... decrépito... um urso....

17 REGIO, 1978. p. 154,

${ }^{48}$ REGIO, 1978. p. 155.

19 RÉGIO, 1978. p. 1555-156. 
Diante do reconhecimento público da impotência do rei, Leonel imagina-se no lugar do rei e cogita: "- Se um dia fosse rei, ouviria todlas as justas reclamações, procuraria atender..." ${ }^{\text {(4) }} \mathrm{O}$ uso do condicional é só porque, neste momento, acabou de descobrir as suas orelhas de burro e está em dúvida se poderá ocupar o lugar de rei. Logo essas incertezas irào se desfazer e irá construir o delírio de que deve, em nome da Verdade, revelar ao povo sua deformidade. Aceito, fari um governo que seri um exemplo para o mundo.

(...) Nào posso começar o meu reinado sob o signo da hipocrisia, da falsidade, da dissimulação, da duplicidade, da mentira... Bem sei que essas forças diabólicas governam o mundo. Mas sonhei um bocadinho do mundo em que elas nào governassem. Esse bocadinho seria o nosso reino de Traslândia; c cle aqui se propagaria ao resto do mundo a grande revoluçào, a única revoluçào progressiva, que é a de dentro de nós contra a nossa depravaçio. Da verdade que possa haver nas minhas palavras duras, - nào tenho, pois, perdões a pedir. Essa, foi Deus que aí a pôs! Temos, todos, de nos curvar a ela, porque nos excede. ${ }^{\text {st }}$

- Nào estou louco! Antes nunca soube tão bem o que digo e faço. Vou mostrar-vos,a todos, que sou um monstro, para que me nåo aceites como vosso rei senão conhecendo a minha disformidade. Cartas na mesa!, e comece o novo mundo.

A certeza de que "eu sou a verclade" é a origem cla agressividade e da violência paranóicas. Quem se contrapor à Verdade encarna o Mal c, como tal, deve ser combatido. Esta é a lógica dos delírios interpretativos, altruista e de grandeza.

$O$ ideal de autenticidade, tão veementemente defendido por José Régio, em seus textos sobre a literatura e em suas teorizaçōes sobre as diretrizes estéticas de Presença, nos remete para JeanJacques Rousseau, a quem Lacan considera um paranóico de gênio.

so RÉGIO, 1978. p. 159.
s1 REGIO, 1978. p. 291.
s2 RÉGIO, 1978. p. $298-299$. 
Tanto o príncipe quanto Rousseau acreditam na transformaçào do mundo, através do governo de um Legislador Virtuoso, que irá modificar os homens e implantar o amor fraterno entre eles:

Aquele que ousa empreender a instituiçào de um povo deve sentirse com capacidade para, por assim dizer, mudar a natureza humana, (...) O Legislador, sob todos os aspectos, é um homem extraordinário no Estado. (...) A grande alma do Legislador é o verdadeiro milagre que deverá autenticar sua missão. ${ }^{53}$

(...) Dizem que as tramóias dos deuses nào podem ser escancaradas ao vulgo. Dizem que a mentira, a astúcia, a duplicidade sào necessárias ao governo do mundo. Assim dizem e em consequiència procedem: No mundo inteiro a grande política é a da falsidade, a da intençio reservada; (...) Pois bem, esta diplomacia de falsidade também nào dá resultado! Já se viu que nảo dá resultado. Por que nào experimentar o contrário? Por que nào tentar a verdade, o esforço pela sinceridade, a humildade luminosa?"

A essência da virtude está no compromisso de dizer toda a verdade. Rousseau abre o seu livro As Confissões, afirmando:

Tomo uma resoluçào de que jamais houve exemplo c que não terá imitador. Quero mostrar aos meus semelhantes um homem $\mathrm{cm}$ toda a verdade de sua natureza, e esse homem serei cu. (...) Somente eu. (...)

Que a trombeta do juizo final soe quando ela bem entender, eu virei, com este livro na mào, apresentar-me diante do juiz supremo. Direi resolutamente: eis o que fiz, o que pensei, o que fui."s

Leonel discursa para seu povo:

(...) Quis Deus, porém, insụflar-me coragem para un momento de santidade: aquele em que me vou mostrar tal qual sou, e humilharme e confessar-me diante de vós todos. Sem isso, nada eu poderia tentar. Como exigir de outrem sinceridade, humildade, Loa vontade,

\footnotetext{
is ROUSSEAU, 1973. p. 63-65.

it REGIO, 1978. p. 282-283.

"SOUSSEAU, 1965. p. 15.
} 
coragem, - começando eu por vos enganar a todos? por consentir em que andeis iludidos comigo? É preciso que bem conheceis, em toda a sua monstruosidade, o rei que ides ter. É preciso que me aceiteis conhecendo-me! $\hat{\mathrm{E}}$ preciso que vos dê o exemplo de quanto exigirei de vós. ${ }^{36}$

A equação de uma verdade absoluta não nos permite pensar o inconsciente como sendo o lugar de produção de um saber, que escapa à intencionalidade do sujeito e se caracteriza pelo não-todo. O compromisso com esta Verdade só pode se realizar no eixo imaginário sem mediação simbólica, fazendo com que o Outro (lugar de fala) seja reduzido ao outro (próximo como semelhante). Feita esta operação, o outro se torna idêntico ao eu. É neste sentido que Lacan insiste em seu ensino que o eu é o outro. Dá relação especular entre o eu e seu duplo se origina o delírio de auto-punição e o desprezo por si mesmo.

Foi o meu profundo desgosto de mim próprio - que me deu olhos com que visse a fealdade e a malvadez gerais. Pois nào nos consolamos, até, do mal que sentimos $\mathrm{cm}$ nós, procurando, contemplando, exagerando o mal nos outros?"?

(...) Foi preciso ver-me tal qual era, e sou, abaixo do mais vulgar homem normal de entre vós, abaixo de qualquer dos vossos aleijados, pois o meu aleijào é caso único no mundo..., - foi preciso isso, para, $\mathrm{cm}$ verdade, ver alguma coisa. ${ }^{\$ M}$

Minhas paixões sào violentíssimas e quando me dominam nào há nada que iguale sua impetuosidade: não conheço mais consideraçiōo, nem respeito, nem medo, nem decência; sou cínico, ousado, violento, intrépido: nåo há vergonha que me faça parar, nem perigo que me meta medo: fora do único objeto que me ocupa, o universo não mais existe para mim.

S. RÉGIO, 1978. p. 292.

"REGIO, 1978. p. 292.

\&EG REIO, 1978. p. 293. 
(...) Nao terminaria nunca com esses detalhes se quisesse seguir todas as veredas pelas quais, durante meu tempo de aprendiz, passei da sublimidade do heroísmo à baixeza dum patife."

Se o Outro é "o lugar onde se constitui o eu que fala com aquele que ouve", (x) toda fala que se dirige ao Outro, enquanto lugar de alteridade, não pode ser reduzida às relações de simetria e de reciprocidade. $O$ tu como significante é radicalmente diferente do eu. Na paranóia, o tu, sem valor de significante, se dirige a um Outro absoluto, transformando-se naquele que observat tudo, que sabe tudo, que emite ordens. Deste Outro absoluto, emana algo que tem alguma relação com a lei, "mas uma lei sem dialética", uma lei que surge como um "imperativo categórico"."1 Leonel, em momento algum, duvida de que foi escolhido por esse tu categórico (Outro absoluto) para realizar uma missão. Lacan, no Seminário 3, As psicoses, afirma que esse tu adquire um caráter de corpo estranho do qual o eu não pode fugir. E, justamente por isto, o eu recebe, sob a forma de delírio, uma ordem inquestionável.

Cabe uma questão para articularmos o delírio de auto-punição com o tu categórico (Outro absoluto). Se as relações que se estabelecem entre o eu e o Outro absoluto são de reciprocidade, como o eu pode experimentar esse Outro absoluto, do qual tudo se origina, como exterior ao seu próprio eu? Pela via da especularidade, a estranhezá desse Outro absoluto se abate sobre o próprio eu e sobre os outros, que, tomados como semelhantes, se apresentam como reflexos especulares do eu.

A imagem de Leonel como príncipe perfeito se torna estranha para si mesma, quando ele se vê com orelhas de burro. Nesta imagem hedionda de si mesmo - onde o tu categórico (Outro absoluto) se apresenta como exterioridade -, Leonel não se reconhece como príncipe perfeito, o que faz com que fuja do

\footnotetext{
9) ROUSSEAU, 1965. p. 48-52.

${ }^{6}$ LACAN, 1985. p. 308.

"LACAN, 1985. p. 311.
} 
palácio e abdique, temporariamente, de sua missão real. Depois, convencido da grandeza de sua missào, momento em que seu eu se funde com o Outro absoluto, o qual se torna seu duplo especular, ele se torna o Grande Reformador de Traslândia, escolhido por Deus. Quando Leonel se apresenta para seu povo através do "Eu sou a Verdade", este Outro absoluto foi de tal forma incorporado que, com firmeza inabalável, pode dizer: Eu tenho uma missão... A mim foi delegado... Nada e ninguém me impedirá de seguir o caminho do bem, da verdade e da justiça... Eis uma fala, sob a forma de delírio, onde "os significantes se põem a falar, a cantar sozinhos".

$\mathrm{Na}$ história de Leonel faltou o significante (Nome-do-Pai) que iria impedir a sua relação sem fronteiras com o Outro, inscrevendoo no regime da Lei e fazendo com que, por mais que o Outro (lugar de fala) fosse imaginarizado, permanecesse na ordem do desconhecido. O Outro, como o lugar de oncle se origina a fala, reaparece pela via da especularidade como sendo seu próprio eu. Por isto Lacan ensina que a linguagem fala sozinha e que, para que um sujeito seja falado por ela, é preciso a inscriçào do significante do Nome-do-Pai.

Leonel não tem mais orelhas de burro. Suas orelhas são "finas, nem grandes nem pequenas, graciosamente relacionadas com $O$ desenho do crânio e da face". ${ }^{63}$ Será que ele as teve um dia? A marca do estranhamento consigo mesmo sumiu, no momento em que seu eu se funde imaginariamente com o Outro absoluto. Leonel, à deriva do gozo do Outro, em puro estado gozante, vendo-se como o mais belo, o mais perfeito e o mais sábio de todos os homens, desaparece deste mundo. Morto, a sua formosura revela, parodiando Lacan, como seria bela uma mulher...

Galaaz também se ofereceu ao gozo do Outro, quando sua alma subiu ao céu. Os poetas barrocos também falam de uma experiência gozante no furo (gozo para além do falo), oncle a vida

62 LACAN, 1985. p. 331.

GS RÉGIO, 1978. p. 301. 
contracena com a morte. Não se trata da mesma coisa. Leonel, ao contrário dos poetas barrocos, nunca imaginou um amor para sempre perdido, a partir de uma relação simbólica. Ao contrário de Galaaz, nunca nasceu para a ordem simbólica do mundo. Sem ser marcado pelo Nome-do-Pai, morre na condição de sujeito do prazer. Nele, não se deu a passagem do sujeito do prazer para o sujeito do desejo.

(...) De cabeça nua, o príncipe Leonel era mais belo. Onde a monstruosidade?!

(...) "Meu Deus!" gritava ininterruptamente uma voz de todo o seu ser. E este grito de fogo era, ao mesmo tempo, uma acçào de graças e uma súplica angustiada: Agora é que ele queria a vida, agora que vencera a sua disformidade, e era agora que ia morrer, sentia-o. ${ }^{65}$

(...) Aquele buraquinho de luz que aumentava, aumentava prodigiosamente, era a porta da evasão;mas jã não era uma estrelinha porque era um mar de luz que o engolia, uma alegria insuportável, verdadeiramente insuportável, que o solevava, o derrubava... Morrer, meu Deus!, agora que ia compreender tudo, ter a chave de tudo? Mas este mar de luz ainda seria mundo? Já nào seria a morte...? Já não seria outra vida.....

Quando deitaram o príncipe Leonel no seu leito de ébano e prata (um dos presentes do bom rei Rodrigo) jả estava morto. Morto, o seu rosto era duma beleza sobre-humana."

Leonel amou Leonilde, amou Letícia. Cada uma, enquanto duplo especular, representa a sua identidade imaginária. É neste sentido que se fala do caráter homossexual da paranóia. Leonilde e Letícia, como instâncias do eu de Leonel, constituem estágios diferentes no processo evolutivo do seu delírio. Leonilde, a que se apresenta como extensão da imagem que Leonel tem de seu próprio corpo, é escolhida antes da descoberta de suas orelhas de burro:

" RÉGIO, 1978. p. 301.
65 REGGIO, 1978. p. 303.
" REGIO, 1978. p. 304.
"REGIO, 1978. p. 305. 
(...) os corpos de Leonel e Leonilde pareciam as duas metades perfeitas dum corpo icleal completo, um par unificado, em que a força e a seca elegância varonis se fundissem, $(. . .)^{\text {its }}$

A semelhança fônica entre os nomes nos é apresentada de forma irônica:

Leonel... Leonilde! Até a maravilhosa coincidência dos seus nomes parecia indicar que desde a pia baptismal casara um alto destino as suas estrelas fulgurantes. Leonel...Leonilde!..."

Esta ironia é reiterada pela fala de Leonilde, quando Leonel, já tendo tomado conhecimento de suas orelhas de burro, se dirige a ela, perguntando se esta continuaria a amá-lo se ele não fosse tão perfeito quanto parecia ser. Na resposta de Leonilde transparece com todas as letras o caráter homossexualizante de um amor que se dirige para a aparência de ser:

- Se vós fôsseis imperfeito, (...) nào vos accitaria; nào vos amaria, porque nào serićs vós! (...) Amo-vos porque sois o homem mais perfeito que encontrei; $c$ porque não creio poder jamais encontrar outro semelhante..."

Leonel, vendo-se como hediondo, troca a imponência da formosura de Leonilde por Letícia, ironicamente mais adequada à imagem de seu corpo com a marca de bicho.

(...) parecia mais velha sendo mais nova, cra uma criatura quase lastimável com o seu modo triste, recolhido, o seu longínquo sorriso como forçado, c os seus olhos a que mal se via a cor, por quase sempre baixos, num oval de rosto pálido e magro. Dir-se-ia uma serva atrís duma rainha."

"H REGIO, 1978. p. 103.

G RF.GIO, 1978. p. 102-103.

خ RÉGIO, 1978. p.226.

"RÉGIO, 1978. p.104. 
Letícia, a feia virtuosa, vê Leonel como extensão de sua própria imagem, já que passa a amá-lo assim que lhe é revelada pelo próprio príncipe a sua disformidade.

- Sou belo! sei que sou belo em todo o resto do meu corpo. Mas tenho uma anomalia grotesca... um pequeno defeito mas ridículo... terrivel... que mulher nenhuma ainda viu... ninguém... só os que me criaram... (...) esforço.

- Eu próprio não sabia... - murmurou ele arquejando do imenso

(...) Oh! - suspirou ela - meu querido!

(...) Não vos faço horror...?

(...) É agora que vos amo... (...) Sou vossa quando me quiserdes... até à morte..."

O príncipe é um personagem situado além do mundo e da vida, que ora se embevece, ora se estranha consigo mesmo, até incorporar o Outro absoluto e morrer entorpecido com a própria imagem, onde se fundem a beleza do corpo com a virtude da alma. Leonel desfalece em gozo mortal, diante do povo, que reconheceu em seu cadáver o que ele sempre acreditou ter sido: um príncipe perfeito sem orelhas de burro. Um príncipe que retorna ao inanimado, livrando-se da lei morte para ressuscitar no ventre de Letícia como o Desejado...

José Régio reescreve a história de Portugal, escolhendo umas das versōes em que o nacionalismo é sustentado por um amor que substitui o desejo pela divinização de um Rei-Morto, um rei que não se apresenta como metáfora dos Nomes-do-Pai. Um Rei que simboliza a potência do Outro absoluto. Um Rei que, um dia... numa manhã de denso nevoeiro... surgirá dos mares, montado em seu cavalo branco... E assim o mundo se transformará num grande e único império cristão, comandado por Portugal, outrora...

${ }^{72}$ REGIO, 1978. p. 232-233. 


\section{Referências Bibliográficas}

A DEMANDA DO SANTO GRAAL. Ed. Irene Freire Nunes. Portugal: Imprensa Nacional - Casa da Moeda, 1995.

Amadis de Gaula. Ed. Juan Manuel Cacho Blccua. Madrid: Ediciones Cátedra, 1996. Col. Letras Hispánicas, 255-256. 2 v.

BENJAMIN, Walter. Origem do drama alenão. Sło Paulo: Brasiliense, 1963.

CAMÒES, Luís de. Os lusiadas. Rio de Janciro: Padrào, 1979.

FREUD, Sigmund. Obras completas. 3. ed. Madrid: Biblioteca Nueva, 1973.

LACAN, Jacques. O seminärio, litmo 3, as psicoses. Rio de Janeiro: Zahar, 1985.

LACAN, Jacques. O seminârio, limro 7, a ética da psicanálise. Rio de Janeiro: Zahar, 1988.

PESSOA, Fernando. Obra em prosa. Rio de Janeiro: Aguilar, 1976.

PIRES, António Machado. D. Sebastião c o encoberto. Lisboa: Fundação Calouste Gulbenkian, 1982.

RÉGIO, José de. Páginas de doutrina e crítica da presença. Porto: Brasília Editora, 1977.

RÉGIO, José de. O principe com orelhas de burro. Porto: Brasília Editorı, 1987. ROUSSEAU, Jean-Jacques. As confissōes. Rio de Janeiro: Ediçôes de Ouro, 1965.

ROUSSEAU, Jean-Jacques. Emilio ou da educação. São Paulo: Martins Fontes, 1995.

ROUSSEAU, Jean-Jacques. Do contrato social. Sào Paulo: Abril Cultuml, 1973. (Col. Os pensadores 24.)

ROUSSEAU, Jean-Jacques. Discurso sobre a origem $c$ os fundamentos da desigualdade entre os homens. Sảo Paulo: Abril cultural, 1973. (Col. Os pensadores 24.) 


\section{Resumo}

A leitura de O principe com orelbas de burro de José Régio visa, principalmente, destacar duas questỏes: os compromissos estéticos de Presença e o recurso da alegoria, no sentido de Walter Benjamin. A apropriaçio de alguns procedimentos narrativos, da lógica mítica e das aventuras cavaleirescas do ciclo bretão inscrevem-se no projeto estético de Presença, que tem como meta incorporar, no presente, "tudo o que é vivo do passado para que se torne clássico no futuro". O recurso da alegoria, apontando para uma relaçào entre texto e contexto, totalmente diferente da concebida pelo neo-realismo, tece uma estória que se passa em um lugar fictício, onde se repetem os acontecimentos e as versỏes que cercarnm o nascimento do rei $D$. Sebastião e que contribuíram para a formação do messianismo sebástico.

\section{Abstract}

The reading of Oprincipe com orelbas de burro, by José Régio, reaches two main points: the aesthetical commitment of "Presença" and the usage of alegory as resource, as it was defined by Walter Benjamin. The appropriation of some narrative procedures, the usage of mythical logic and cavalieresque adventures from the Breton cycles. These element automatically undenake the aesthetical arguments used by "Presença" that had itself the objective of incorporating, in present," all alive remainings from past, in order that they become classical in future". The alegory establishes a link between text and context in a different way from the one conceived by neo-realism. It tells a story that takes place in a fictional site, in which facts and versions evoke the birth of the King Dom Sebastiato, reinforcing the formation of messianic sebastianism. 